\title{
Development of A Web-based English Teaching Course to Increase Nursing Students' Information Literacy Competency
}

\author{
Ching-Yu Cheng ${ }^{1}$ Shwu-Ru Liou ${ }^{1}$ Wei-Chieh Yu ${ }^{1}$ Hsiu-Min Tsai ${ }^{2}$ \\ ${ }^{1}$ Chang Gung University of Science and Technology, Chiayi \\ ${ }^{2}$ Chang Gung University of Science and Technology, Linkou
}

\begin{abstract}
This study aimed to develop a web-based course to cultivate nursing students' information literacy competency. The study was a three-semester study that included a development of the course, pilot-test and modification of the course design, and final implementation of the modified course design. All class activities were done online except for periodical meetings for problem discussions. The results showed that the majority of students possessed positive thoughts about the teaching method, understood more about information literacy and could apply information literacy skills in nursing. This teaching model for information literacy can be references for educators to develop online courses.
\end{abstract}

Keywords: web-based learning, information literacy, nursing

\section{Introduction}

Because of the rapid changes on computer and internet technologies and proliferation of information resources, information competency or information literacy becomes increasingly important. According to the Association of College and Research Libraries, information literacy is defined as "a set of abilities requiring individuals to recognize when information is needed and have the ability to locate, evaluate, and use effectively the needed information" [1]. Different from computer skills that are merely computer use [1,2], information literacy involves understanding, accessing, evaluating, incorporating information into knowledge base, and using information effectively and correctly [1]. It contributes to self-directed lifelong learning and is considered as outcome abilities of college students [1]. In health profession, study results showed that nurses' competency in retrieving and using internet information could support patients and families to use internet as a medium to obtain information since the Internet became an accessible information source [3]. However, a literature review article pointed out that information literacy was a relatively new concept in health profession including nursing and there was especially a lack of publications about information literacy from Asian countries [4].
More health related academic and clinical institutions emphasize evidence-based practice to provide patients with safe and proper care. However, researchers pointed out that lack of time, lack of information accessibility and technology skills, and inadequate information search and appraisal skills were barriers for nurses to obtain proper information and perform evidenced-based practice. These lacks of information literacy skills lead nurses to use information that was accessible and convenient to them rather than to use information with quality [5]. What worsened the situation were the publication biases namely selection bias, confounders, observation bias, and allocation concealment, in medical publications [6]. Information available to the public could be biased and nurses then could apply improper information to patients.

Current undergraduate nursing students mainly belong to Millennial generation, who were born between 1982 and 2002 [7]. These Millennial students grew up with computers and in the Internet world. They respond to text messages and blogging, use online social networking tools such as facebook more often than traditional communication pathways [8-10], obtain information or discuss school work on web. In other words, traditional lectures are no longer appreciated ways of teaching and learning. On the contrary, web-based learning could be a better way to teach. However, although most university students perceived themselves having good research skills, they could not perform accurate information searches or judge trustworthiness of health-related websites. They were also unclear about the concept of plagiarizing and citing references [11]. Therefore, there is a need to teach concept of information literacy and how information literacy is applied in health professions.

The purpose of this study was to develop a web-based course that cultivated nursing students' competency in information literacy. After the class, nursing students should be able to apply information literacy skills in nursing. This study was a three-semester (one and a half years) study. We developed a web-based course in the first semester. In the second semester, we held a seminar to evaluate the course and an end-of-semester student presentation. Students also provide suggestions about the course in a questionnaire. Based on the discussions in the seminar and student suggestions, the course was modified. The third semester was an implementation of the modified course design. 


\section{Methods}

\subsection{Theoretical Background of the Course}

Information literacy focuses on content, communication, analysis, information searching, and evaluation [12]. To gain these abilities, the concept and skills of information literacy should be woven into the curriculum's content, structure, and sequence [1]. The dimensions of information literacy that include tool/emerging technology literacy, resource literacy, social-structural literacy, research literacy, publishing literacy, and critical literacy [13] were used to structure the course. The objectives of the course were set based on the standards for information literacy competency for higher education proposed by the Association of College and Research Libraries. The standards include determining the nature and extent of the information needed, accessing needed information effectively and efficiently, critically evaluating information and its sources, incorporating information into knowledge base, using information effectively, accessing and using information ethically and legally [1]. Students' information literacy skills were practiced when they did assignments and published/presented final projects in public.

\subsection{Design of the Course}

The structure and topics of this web-based course was based on dimensions of information literacy and is shown in Figure 1. Assignments in the course included learning journals, literature search, website critique, discussion forums of literacy issues such as academic integrity, and final project focusing on health-related issues. The majority of the classes were taught/discussed online and students and the instructors met periodically only for clarification or problems discussion. All other class activities were done online. The platform for online teaching (e-campus) used in our school was used for this course. The platform includes sections of class information, bulletin board, class unit/note, assignment, discussion board, quiz, and questionnaire. We set up the course before the semester began and updated all materials including announcements periodically. Examples of each section were presented in Figure 2 to Figure 6.

\subsection{Sample and Sampling}

We recruited only senior nursing students in the study because students had to have knowledge about health and nursing in order to complete a health-related project. Also, since the course was taught in English, only students who passed an English proficiency test could enroll in the course. Before the semester began, we introduced the course to all senior nursing students in our school and set up a time for students who were interested in the course to take an English proficiency exam. Twenty-one and eighteen students enrolled in the first and third semester of the study.

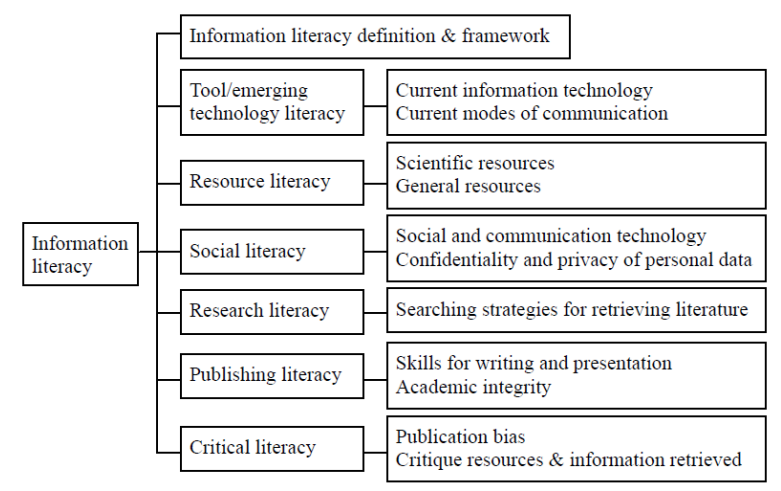

Fig. 1: Structure of the course.

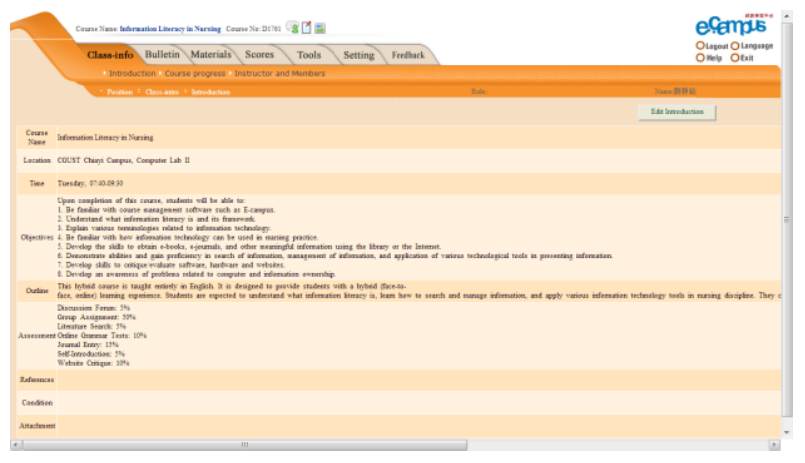

Fig. 2: Class information.

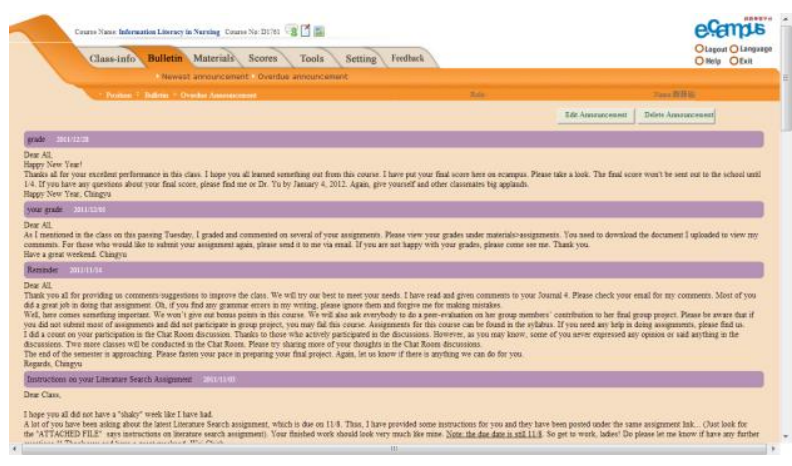

Fig. 3: Bulletin board for announcements.

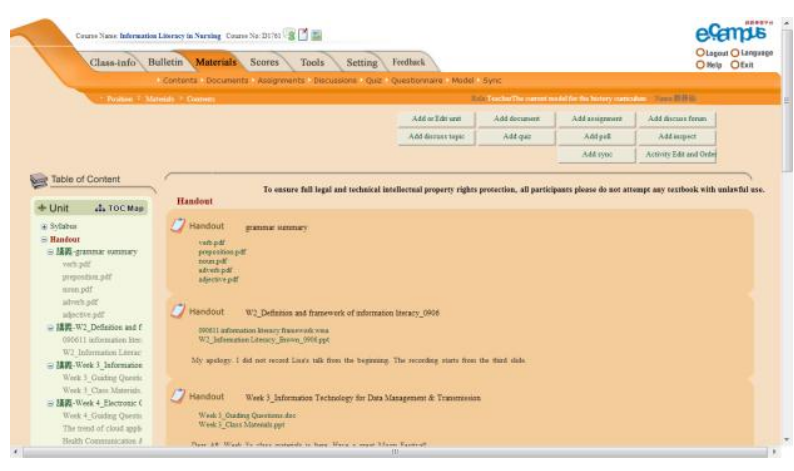

Fig. 4: Class materials. 


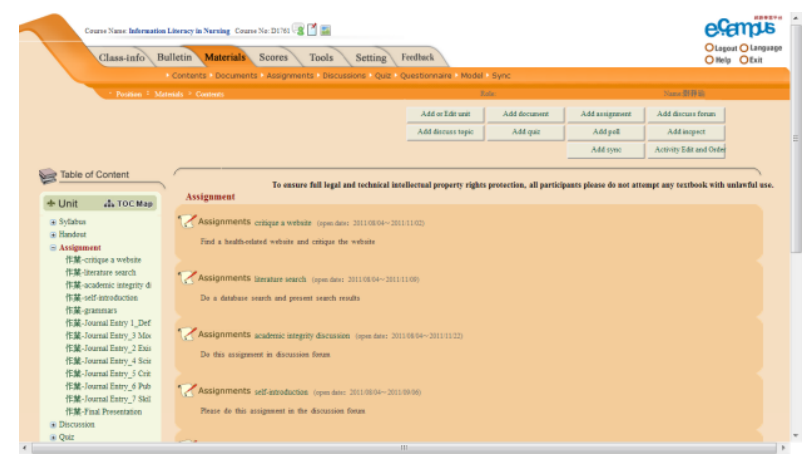

Fig. 5: Assignments for the class.

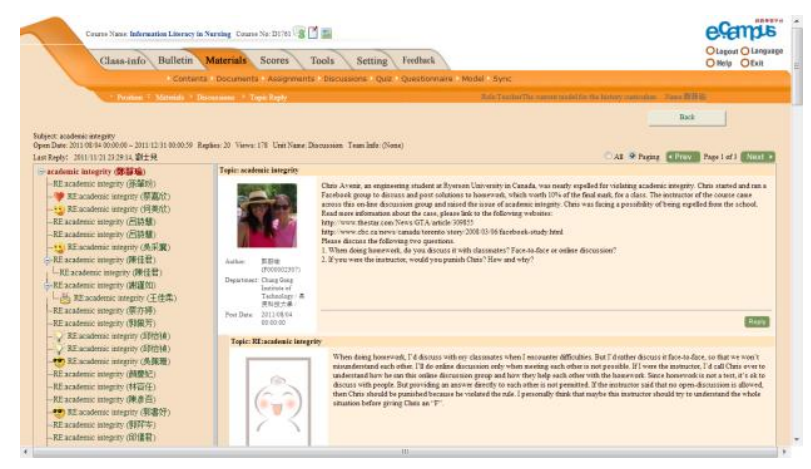

Fig. 6: Discussion board.

\subsection{Course evaluation}

The course was evaluated at the end of the semester by 15 questions related to computer-mediated teaching strategy (8 questions) and information literacy (7 questions). Questions are presented in Table 1. Students were asked to rate their level of satisfaction about computer-mediated teaching/learning strategies and learning outcomes after taking the course.

\subsection{Results}

As shown in Table 1, the majority of students possessed positive thoughts about computer-mediated learning that was used in the course and could apply information literacy skills in nursing after completing the course.

\subsection{Conclusion}

This study aimed to develop a web-based course to cultivate nursing students' competency in information literacy. The study was a three-semester study that included a development of the course, pilot test and modification of the course design, and final implementation of the modified course design. All class activities were done online except for periodical meetings for clarifications and problem discussions. The results showed that the majority of students possessed positive thoughts about the teaching method and understood more about information literacy and could apply information literacy skills in nursing. This teaching model for information literacy can be a reference for other educators to develop online courses.

Table 1. Perception of Compute-mediated Learning and Learning Outcomes.

\begin{tabular}{|l|c|c|c|}
\hline & $\begin{array}{c}\text { Strongly } \\
\text { agree (\%) }\end{array}$ & $\begin{array}{c}\text { Agree } \\
(\%)\end{array}$ & $\begin{array}{c}\text { Neutral } \\
(\%)\end{array}$ \\
\hline Web-based learning & & & \\
\hline Allows knowledge building. & 58.8 & 41.2 & 0.0 \\
\hline $\begin{array}{l}\text { Promotes in-depth and } \\
\text { advanced learning. }\end{array}$ & 58.8 & 41.2 & 0.0 \\
\hline $\begin{array}{l}\text { Allows building computer } \\
\text { skills. }\end{array}$ & 64.7 & 35.3 & 0.0 \\
\hline $\begin{array}{l}\text { Ensures that students are } \\
\text { engaged and motivated in } \\
\text { learning }\end{array}$ & 35.3 & 47.1 & 17.6 \\
\hline $\begin{array}{l}\text { Encourages collaborative } \\
\text { (group) learning }\end{array}$ & 29.4 & 52.9 & 17.7 \\
\hline $\begin{array}{l}\text { Enables effective } \\
\text { communication with the teacher } \\
\text { and peers. }\end{array}$ & 23.5 & 76.5 & 0.0 \\
\hline Helps lifelong learning. & 76.5 & 23.5 & 0.0 \\
\hline Promotes self-learning. & 58.8 & 35.3 & 5.9 \\
\hline After completing the course, I & 64.7 & 35.3 & 0.0 \\
\hline $\begin{array}{l}\text { Am more familiar with and } \\
\text { capable of using various } \\
\text { learning programs such as } \\
\text { e-campus. }\end{array}$ & 41.2 & 52.9 & 5.9 \\
\hline $\begin{array}{l}\text { Understand more about } \\
\text { information literacy and its } \\
\text { framework. }\end{array}$ & 57.1 & 52.9 & 0.0 \\
\hline $\begin{array}{l}\text { Can explain clearly terms } \\
\text { related to information literacy. }\end{array}$ & 58.8 & 5.9 \\
\hline $\begin{array}{l}\text { Know how to apply information } \\
\text { literacy skills in nursing. }\end{array}$ & 47.2 & 58.8 & 0.0 \\
\hline $\begin{array}{l}\text { Can effectively use e-books, } \\
\text { e-journals, world web wide, and } \\
\text { information sources in library. }\end{array}$ & 58.8 & 0.0 \\
\hline $\begin{array}{l}\text { Can organize and manage } \\
\text { information more effectively. }\end{array}$ & & & \\
\hline $\begin{array}{l}\text { Can use various information } \\
\text { nursing information. }\end{array}$ & 47.1 & 0.0 \\
\hline
\end{tabular}

Note. No students chose categories of "disagree" or "strongly disagree." These two categories were not presented in the Table.

We acknowledge the Center for Teaching \& Learning Excellence in Northern Region, Ministry of Education (4-3-C-1) in Taiwan for funding this study. Correspondence to Shwu-Ru Liou.

\section{References}

[1] Association of College \& Research Libraries, Information literacy competency standards for higher education. Chicago: Association of College \& Research Libraries, 2000.

[2] D.B. Bryson, The computer literate nurse. Computers 
in Nursing, 9(3), 100-107, 1991.

[3] J.A. Gilmour, S.D. Scott, N. Huntington, Nurses and internet health information: a questionnaire survey. Journal of Advanced Nursing, 61(1), 19-28, 2008.

[4] K. Saranto, E.J.S. Hovenga, Information literacy-what it is about? literature review of the concept and the context. International Journal of Medical Informatics, 73, 503-513, 2004.

[5] R. Bertulis, Barriers to accessing evidence-based information. Nursing Standard, 22(36), 35-39, 2008

[6] J.Cohen, A new 'publication bias': the mode of publication. Reproductive Biomedicine online, 13(5), 754-755, 2006.

[7] W.Strauss, N. Howe, Miltennials rising: The next great generation. New York, NY: Vantage Press, 2000.

[8] T. DeBoor, L.K. Halpem, Creating \& connecting: Research and guidelines on online social and educational networking. Retrieved from http://www.nsba.org/site/view.asp?CID=63\&DID=4 1340.

[9] A. Lenhart, M. Madden, P. Hitlin, Teens and technology; Youth are leading the transition to a fully wired and mobile nation. Washington, DC: Pew Internet \& American Life Project, 2005.

[10] A. Lenhart, K. Purcell, A. Smith, K. Zickhur, Social media \& mobile Internet use among teens and young adults. Washington, DC: Pew Internet \& American Life Project. Retrieved from http://pewintemet.org/Reports/2010/Social?Media?a nd?Young?Adults.aspx

[11] L. Ivanitskaya, I.O'. Boyle, A.M. Casey, Health information literacy and competencies of information age students: results from the interactive online research readiness self-assessment (RRSA).

Journal of Medical Internet Research, 8(2), e6. 2006

[12] National Research Council. Commission on Physical Sciences, Mathematics, and Applications. Committee on Information Technology Literacy, Computer Science and Telecommunications Board. Being Fluent with Information Technology. Washington, D.C.: National Academy Press, 1999. http://www.nap.edu/books/030906399X/html/

[13] J.J. Shapiro, S.K. Hughes, Information literacy as a liberal art. Educom Review, 31(2), http://net.educause.edu/apps/er/review/reviewarticles /31231.html 